\title{
Prediksi Jumlah Calon Mahasiswa Baru Tahun 2018-2022 di Poltekkes Kemenkes Semarang
}

\author{
Forecasting the Number of New Students \\ in Poltekkes Kemenkes Semarang in 2018-2022
}

\author{
Adhani Windarii ${ }^{1)}$; Emi Murniati ${ }^{2)}$ \\ 1,2)Jurusan Rekam Medis dan Informasi Kesehatan: Poltekkes Kemnekes Semarang \\ Jl. Tirto Agung, Pedalangan, Banyumanik, Semarang
}

\begin{abstract}
Campus managers must be sensitive to consumers in the marketing process, students are important assets in college life, strategies and regular promotions have a correlation with the number of registrants. Data analysis for 5 years from 2013 to 2017 provides precise accuracy every year and can be used as a reference for predicting new student admissions in the following year. The growth in the number of new student admissions has an impact on providing lecture halls and improving services. One method for research related to the right prediction is to use non linear regression analysis.

The results of predictions with non linear regression analysis indicate an increase in the number of registrants and decreases each year.
\end{abstract}

Keyword: prediction of acceptance of the number of students

\begin{abstract}
Abstrak
Pengelola kampus harus sensitif terhadap konsumen pada proses pemasaran, mahasiswa adalah aset penting dalam kehidupan Perguruan Tinggi, strategi dan promosi reguler mempunyai korelasi terhadap jumlah pendaftar. Analisis data selama 5 tahun dari tahun 2013 sampai dengan 2017 memberikan akurasi yang tepat setiap tahunnya dan bisa dijadikan acuan prediksi penerimaan mahasiswa baru pada tahun setelahnya. Pertumbuhan jumlah penerimaan mahasiswa baru berdampak pada penyediaan ruang kuliah dan peningkatan pelayanan. Salah satu metode untuk penelitian berkaitan dengan prediksi yang tepat adalah menggunakan analisis regresi non linear.

Hasil prediksi dengan analisis regresi non linier menunjukkan adanya peningkatan jumlah pendaftar maupun penurunan setiap tahunnya.
\end{abstract}

Kata Kunci: prediksi penerimaan jumlah mahasiswa

\section{Pendahuluan}

Poltekkes Kemenkes Semarang merupakan institusi pendidikan yang menyelenggarakan pendidikan dalam bidang kesehatan yang berada dibawah naungan Kementerian Kesehatan Republik Indonesia. Poltekkes Kemenkes Semarang menyelenggarakan pendidikan Diploma III, Diploma IV dan Program Pasca Sarjana. Saat ini memiliki 8 jurusan yang terdiri dari 8 program studi Diploma IV, 22 program studi Diploma III dan 4 program studi Magister Terapan Kesehatan dan tersebar di

8 wilayah Kampus, yaitu Kampus I dan III di Semarang, Kampus IV di Blora, Kampus V di Magelang, Kampus VI di Pekalongan, Kampus VII dan VIII di Purwokerto.

Setiap tahun Poltekkes Kemenkes Semarang menyelenggarakan penerimaan mahasiswa baru, melalui 3 jalur, yaitu Jalur Umum, Jalur PMDP (Penelurusan Minat dan Prestasi) dan Jalur Mandiri. Proses penerimaan mahasiswa baru dari tahun ke tahun mengalami perbaikan sehingga dapat diketahui oleh masyarakat secara terbuka. 
Dalam penentuan hasil kelulusan calon mahasiswa baru diperlukan beberapa pertimbangan yang cukup banyak sesuai dengan standard yang telah ditentukan serta kebijakan-kebijakan pimpinan yang sering berubah setiap tahunnya.

Jumlah pendaftar calon mahasiswa baru di Poltekkes Kemenkes Semarang setiap tahunnya mengalami peningkatan dan juga mengalami pernah mengalami penurunan, baik dalam jumlah keseluruhan maupun dibeberapa program studi. Data dari Bagian Administrasi Akademik Poltekkes Kemenkes Semarang pada tahun akademik 2011/2012 sampai dengan 2015/2016 menunjukkan bahwa jumlah pendaftar di Poltekkes Kemenkes Semarang sebagai berikut :

Tabel 1. Presentase Peningkatan dan Penurunan

Jumlah Pendaftar Tahun 2011-2016di Poltekkes Kemekes Semarang

\begin{tabular}{cccccc}
\hline Tahun & $\mathbf{2 0 1 1 / 2 0 1 2}$ & $\mathbf{2 0 1 2 / 2 0 1 3}$ & $\mathbf{2 0 1 3 / 2 0 1 4}$ & $\mathbf{2 0 1 4 / 2 0 1 5}$ & $\mathbf{2 0 1 5 / 2 0 1 6}$ \\
\hline Jumlah Pendaftar & 7473 & 7147 & 6458 & 6603 & 145 \\
Selisih & - & -326 & -689 & 165 & $2,2 \%$ \\
Presentase & - & $-4,4 \%$ & $-9,6 \%$ & $2,5 \%$ \\
Peningkatan/Penurunan & & &
\end{tabular}

Prediksi jumlah mahasiswa pada suatu institusi Perguruan Tinggi sangat penting dilakukan, karena dengan adanya prediksi jumlah mahasiswa tersebut, maka suatu institusi Perguruan Tinggi dapat membuat suatu perencanaan atau pengambilan keputusan untuk kemajuan suatu Perguruan Tinggi. Dalam hal ini perencanaan yang dapat dilakukan oleh suatu Perguruan Tinggi berdasarkan hasil prediksi jumlah mahasiswa pada waktu yang akan datang, adalah dengan menentukan jumlah kelas yang akan dibuka, jumlah dosen pengajar, jumlah pegawai sebagai tenaga pendidik, jumlah sarana dan prasarana yang harus mendukung, pembuatan jadwal perkuliahan, semua ini memerlukan waktu, tenaga dan ketelitian dalam perencanaannya.

\section{Metode}

Jenis penelitian yang digunakan dalam penelitian ini adalah penelitian dengan pendekatan kuantitatif. Penelitian dengan pendekatan kuantitatif merupakan penelitian yang menekankan pada proses analisis data-data numerikal (angka) yang diolah dengan metode statistika (Azwar,2012). Metode yang digunakan yaitu metode penelitian Kuantitatif dengan pendekatan deskriptif. Metode penelitian deskriptif adalah menganalisis dan menyajikan fakta secara sistematik sehingga dapat lebih mudah untuk dipahami dan disimpulkan (Azwar, 2012). . Hasil perhitungan kemudian dilakukan analisis trend. Cara pengukuran menggunakan analisis trend Non linear. Non Linear Tren adalah salah satu metode yang digunakan dalam analisis tren untuk data jangka panjang dan tidak kontinu.

\section{Hasil dan Pembahsan}

Berdasarkan data jumlah pendaftar dari bagian kemahasiswaan Poltekkes Kemenkes Semarang tahun ajaran 2013/2014 sampai dengan 2017/2018, telah dilakukan perhitungan peramalan/prediksi jumlah pendaftar 5 tahun kedepan, dengan menggunakan analisis regresi non linear. Prediksi jumlah pendaftar tahun 2018-2022 dilakukan berdasarkan asal sekolah, berdasarkan jalur masuk dan minat jurusan / program studi yang dipilih.

a. Prediksi Jumlah Pendaftar Tahun 2018-2022 di Poltekkes Kemenkes Semarang Berdasarkan Asal Sekolah 1) Asal Sekolah SMA Swasta

Tabel 2 memperlihatkan hasil prediksi jumlah pendaftar selama 5 tahun kedepan yang berasal dari SMA swasta dengan menggunakan model regresi non linier power setiap tahun cenderung mengalami 
penurunan

Tabel 2. Prediksi Lima Tahun Kedepan Jumlah

\begin{tabular}{cc} 
Pendaftar dari SMA Swasta \\
\hline Tahun & Prediksi \\
\hline 2018 & 807.32 \\
2019 & 785.26 \\
2020 & 766.63 \\
2021 & 750.57 \\
2022 & 736.49 \\
\hline
\end{tabular}

Tabel 3. Prediksi Lima Tahun Kedepan Jumlah Pendaftar dari SMA Negeri

\begin{tabular}{cc}
\hline Tahun & Prediksi \\
\hline 2018 & 6373.3 \\
2019 & 6371.2 \\
2020 & 6369.4 \\
2021 & 6367.9 \\
2022 & 6366.5 \\
\hline
\end{tabular}

Tabel 4 Prediksi Lima Tahun Kedepan Jumlah Pendaftar dari MA Swasta

\begin{tabular}{cc}
\hline Tahun & Prediksi \\
\hline 2018 & 232.07 \\
2019 & 233.8 \\
2020 & 235.31 \\
2021 & 236.65 \\
2022 & 237.85 \\
\hline
\end{tabular}

Tabel 5. Prediksi Lima Tahun Kedepan Jumlah Pendaftar dari MA Negeri

\begin{tabular}{cc}
\hline Tahun & Prediksi \\
\hline 2018 & 600.82 \\
2019 & 610.44 \\
2020 & 620.21 \\
2021 & 630.15 \\
2022 & 640.24 \\
\hline
\end{tabular}

Tabel 6. Prediksi Lima Tahun Kedepan Jumlah Pendaftar dari SMK Swasta

\begin{tabular}{cc}
\hline Tahun & Prediksi \\
\hline 2018 & 935.79 \\
2019 & 1011.2 \\
2020 & 1081.3 \\
2021 & 1147.3 \\
2022 & 1209.7 \\
\hline
\end{tabular}

Tabel 7. Prediksi Lima Tahun Kedepan Jumlah

\begin{tabular}{cc} 
Pendaftar dari SMK Negeri \\
\hline Tahun & Prediksi \\
\hline 2018 & 232.16 \\
2019 & 245.1 \\
2020 & 256.9 \\
2021 & 267.77 \\
2022 & 277.89 \\
\hline
\end{tabular}

Tabel 8. Prediksi Lima Tahun Kedepan Jumlah Pendaftar dari Kesetaraan/Pindahan/dll

\begin{tabular}{cc}
\hline Tahun & Prediksi \\
\hline 2018 & 108.06 \\
2019 & 115.48 \\
2020 & 122.31 \\
2021 & 128.67 \\
2022 & 134.64 \\
\hline
\end{tabular}

2) Asal Sekolah SMA Negeri

Tabel 3 menunjukkan prediksi jumlah pendaftar yang berasal dari SMA Negeri dengan menggunakan model regresi non linier power cenderung mengalami penurunan setiap tahunnya.

3) Asal Sekolah Madrasah Aliyah (MA) Swasta

Tabel 4 menunjukkan prediksi jumlah pendaftar yang asal sekolahnya dari MA swasta dengan menggunakan model regresi non linier Power mengalami peningkatan setiap tahunnya.

4) Asal Sekolah Madrasah Aliyah (MA) Negeri

Tabel 5 menunjukkan prediksi jumlah pendaftar yang asal sekolahnya dari MA negeri dengan menggunakan model regresi non linier eksponensial mengalami peningkatan setiap tahunnya.

5) Asal Sekolah SMK Swasta

Tabel 6 menunjukkan prediksi jumlah pendaftar yang asal sekolahnya dari SMK swasta dengan menggunakan model regresi non linier power mengalami peningkatan setiap tahunnya.

6) Asal Sekolah SMK Negeri

Tabel 7 menunjukkan prediksi jumlah pendaftar yang asal sekolahnya dari MA negeri dengan menggunakan model regresi non linier power mengalami peningkatan setiap tahunnya.

\section{7) Asal Sekolah dari kesetaraan SMA/pindahan/dll}

Tabel 8 menunjukkan prediksi jumlah pendaftar yang asal sekolahnya dari kesetaraan/pindahan dan lain-lain dengan menggunakan model regresi non linier power mengalami meningkatan setiap tahunnya.

Berdasarkan hasil diatas prediksi jumlah pendaftar di Poltekkes Kemenkes Semarang ada yang mengalami 
peningkatan maupun penurunan. Penurunan terjadi pada asal sekolah SMA baik negeri maupun swasta. Prediksi penurunan jumlah pendaftar perlu diantisipasi dengan memaksimalkan kegiatan promosi baik dari Direktorat maupun Jurusan/Prodi ke sekolah-sekolah khususnya SMA negeri maupun swasta.

\section{b. Prediksi Jumlah Pendaftar Tahun 2018- 2022 di Poltekkes Kemenkes Semarang Berdasarkan Jalur Masuk}

Tabel 9. Prediksi Lima Tahun Kedepan Jumlah Pendaftar Jalur Masuk PMDP Per

\begin{tabular}{cc}
\multicolumn{2}{c}{ Tahun } \\
\hline Tahun & Prediksi \\
\hline 2018 & 2314.7 \\
2019 & 2389.4 \\
2020 & 2457.4 \\
2021 & 2519.8 \\
2022 & 2577.6 \\
\hline
\end{tabular}

Tabel 10 .Prediksi Lima Tahun Kedepan Jalur Umum Per Tahun

\begin{tabular}{cc}
\hline Tahun & Prediksi \\
\hline 2018 & 6389.1 \\
2019 & 6461.6 \\
2020 & 6526.3 \\
2021 & 6584.6 \\
2022 & 6637.8 \\
\hline
\end{tabular}

Tabel 11. Prediksi Lima Tahun Kedepan

\begin{tabular}{cc} 
Jalur Masuk Mandiri Per Tahun \\
\hline Tahun & Prediksi \\
\hline 2018 & 1263.6 \\
2019 & 1305.8 \\
2020 & 1349.4 \\
2021 & 1394.5 \\
2022 & 1441 \\
\hline
\end{tabular}

\section{1) Jalur Masuk melalui PMDP (Penulusuran Minat dan Prestasi) per Tahun}

Tabel 9 menunjukkan bahwa prediksi jumlah pendaftar melalui Jalur PMDP dalam 5 tahun kedepan dengan menggunakan model regresi non linier Power mengalami peningkatan setiap tahunnya.

\section{2) Jalur Masuk Umum per Tahun}

Tabel 10 menunjukkan bahwa prediksi jumlah pendaftar melalui Jalur Umum dalam 5 tahun kedepan dengan menggunakan model regresi non linier Power mengalami peningkatan setiap tahunnya.

\section{3) Jalur Masuk Mandiri per Tahun}

Tabel 11 menunjukkan bahwa prediksi jumlah pendaftar melalui Jalur Mandiri dalam 5 tahun kedepan dengan menggunakan model regresi non linier ekponential mengalami peningkatan setiap tahunnya.

Berdasarkan hasil penelitian di atas, prediksi jumlah pendaftar dalam SIPENMARU dari jalur umum, jalur PMDP dan jalur mandiri secara keseluruhan mengalami peningkatan setiap tahunnya. Peningkatan jumlah pendaftar dapat digunakan sebagai bahan informasi bagi pimpinan dalam pengambilan keputusan tentangpenentuan jumlah kelas yang akan dibuka, jumlah dosen pengajar, jumlah tenaga kependidikan, jumlah sarana dan prasarana yang harus mendukung, pembuatan jadwal perkuliahan dan lainlain.

c. Prediksi Jumlah Pendaftar Tahun 2018-2022 di Poltekkes Kemenkes Semarang Berdasarkan Minat Program Studi yang Dipilih.

Prediksi jumlah pendaftar baik di Prodi Diploma III maupun Diploma IV terjadi peningkatan setiap tahunnya, tetapi ada beberapa prodi mengalami penurunan yang signifikan setiap tahunnya, misalnya Prodi Diploma III Kebidanan. Prediksi peningkatan yang cukup signifikan juga terjadi misalnya pada prodi D III RMIK. Peningkatan tersebut dapat terjadi karena kebutuhan akan tenaga perekam medis dan informasi kesehatan di sarana pelayanan kesehatan saat ini cukup tinggi.Mudahnya mendapatkan lapangan kerja setelah lulus menjadi salah satu daya tarik bagi masyarakat untuk melanjutkan pendidikan di suatu program studi. Prediksi penurunan jumlah pendaftar di Poltekkes Kemenkes Semarang di beberapa program studiDiploma III dan Diploma IV dapat dijadikan bahan pengambilan keputusan bagi pimpinan dalam menyusun kebijakan 
terhadap keberlangsungan program studi tersebut, startegi pemasaran untuk menjaring minat masyarakat, melakukan promosi ke sekolah-sekolah, serta melakukan inovasi pengembangan program studi baru.

\section{Simpulan dan Saran}

Kesimpulan dalan penelitian ini adalah prediksi jumlah calon mahasiswa Poltekkes Kemenkes Semarang berdasarkan asal sekolah dengan katagori asal sekolah, jalur masuk dalam SIPENMARU dan peminatan program studi baik Diploma III maupun Diploma IV ada peningkatan tetapi dan penurunan setiap tahunnya. Adapun saran dalam penelitian ini adalah diperlukan data pendukung yang lengkap agar hasil prediksi lebih akurat.

\section{Ucapan Terimakasih}

Dalam penyusunan penelitian ini penulis banyak mendapat saran, kritik, dorongan, bimbingan serta keteranganketerangan dari banyak pihak, yang menjadikan penulis dapat menyusun karya tulis ini dengan baik dan dapat dipertanggungjawabkan. Oleh karena itu dengan segala hormat dan kerendahan hati perkenankan penulis mengucapkan terimakasih untuk seluruh pihak yang terlibat dalam penyusunan karya tulis ilmiah ini.

\section{Daftar Pustaka}

Ayuningtyas, dkk. (2017). Analisa Perbandingan Logic Fuzzy Metode Tsukamoto, Sugeno, dan Mamdani (Studi Kasus : Prediksi Jumlah Pendaftar Mahasiswa Baru Fakultas Sains dan Teknologi Universitas Islam Negeri Sunan Gunung Djati Bandung). UIN Sunan Gunug Djati Bandung : Jurnal Teknik Informatika, April 2017 h 9-16.

Azwar, Saifuddin. (2012). Metode Panelitian. Yogyakarta:Pustaka Pelajar
Buku VI Matriks Penilaian Instrumen Akreditasi Program Studi Lembaga Akreditasi Perguruan Tinggi Kesehatan,2012.

Castro, Gregorio Martin-de, Pedro LopezSaez and Miriam Delgado-Verde. (2011). Towards A Knowledge-Based View of Firm Innovation:Theory and Empirical Research, Journal of Knowledge Management, Vol.15. No.6. h. 871-874

Dajan, Anto. 1986. Pengantar Metode Statistik. Jilid I. Jakarta: LP3ES.

Darroch, J. Dan R. McNaughton. (2002). Examining the Link between Knowledge Management Practices and Types of Innovation, Journal of Intellectual Capital, Vol.3, No.3, h. 210-222

Desvina, AP. (2014). Penerapan Metode Box-Jenkins untuk Memprediksi Jumlah Mahasiswa Universitas Islam Negeri Suska Riau. UIN Suska Riau : Jurnal Sains, Teknologi dan Indistri Vol.12 No.1 h 80-89.

Dhewanto, wawan dkk., (2014). Manajemen Inovasi. Yogyakarta:Andi

http://ban-

pt.kemdikbud.go.id/hasil_aipt.php,

Tanggal : 07/02/2017

http://sipenmaru.poltekkes-smg.ac.id, Tanggal : 9 Februari 2018

Harliana, dkk. (2017). Prediksi Jumlah Pendaftaran Calon Mahasiswa Baru dengan Metode Regresi linear. Ilmu Komputer STIKOM Poltek Cirebon: Jurnal Ilmiah DASI Vo.18 No 3. H 1-5.

Junaidi, J. (2014). Analisis Hubungan Deret Waktu untuk Peramalan. Jambi. Fakultas Ekonomi dan Bisnis Universitas Jambi. 
Kuncoro, Mudrajad. (2011). Metode Kuantitatif. Yogyakarta:UPP STIM YKPN

Makridakis, S., Wheelwright, S. C., \& Hyndman, R. J. (2008). Forecasting methods and applications. John wiley \& sons.

Mambang, dkk. (2015). Prediksi Calon Mahasiswa Baru menggunakan

Pahlevi, MR. (2016). Kombinasi Algoritma Genetika dan Algoritma Fuzzy Time Series dalam Memprediksi Jumlah Calon Mahasiswa Baru Stikom Dinamika Bangsa Jambi. STIKOM Dinamika Bangsa Jambi : Jurnal Ilmiah Medis Processor Vol.11 No.2 h 829-838.

Peraturan Pemerintah Republik Indonesia Nomor 66 tahun 2010 tentang Perubahan atas Peraturan Pemerintah Nomor 17 tahun2010 tentang Pengelolaan dan Penyelenggaraan Pendidikan.

Purwantoro. (2017). Analisis Prediksi Penerimaan Mahasiswa Baru dengan Menggunakan Metode Regresi. UNSIKA : Jurnal Rekayasa Informasi Vol.6 N0.1 h.1-15

Purba, Agustina. (2015). Perancangan Aplikasi Peramalan Jumlah Calon Mahasiswa Baru yang Mendaftar Menggunakan Metode Single Exponential Smothing (Studi Kasus: Fakultas Agama Islam UISU). STIMIK Budi Darma Medan : Jurnal Riset komputer Vol.2 No.6 h 8-12.

Pusat Statistik Pendidikan Badan Penelitian dan Pengembangan Departemen Pendidikan Nasional Republik Indonesia.
Metode Klasifikasi Decision Tree. AKBID Sari Mulia Banjarmasin : CSRID Journal Vol.7 No.1 h 46-54.

Notoadmodjo, Soekidjo. (2012). Metodologi Penelitian Kesehatan. Jakarta:Rineka Cipta

Nugroho. 1982. Sendi-sendi Statistika. Jakarta: CV. Rajawali.

Render, Barry \& Jay Heizer. 2006. Manajemen Operasi. Edisi ketujuh. Jakarta : Salemba Empat.

Subartini, B., Supriatna, A., Hertini, E., \& Aridin, L. (2017, November). PREDIKSI JUMLAH KEDATANGAN WISATAWAN MANCANEGARA KE JAWA BARAT MENGGUNAKAN METODE TREND KUBIK. In Prosiding Seminar Nasional Pendidikan Matematika (Vol. 1, No. 1).

Sunyoto, Danang. (2016). Statistik Deskriptif dan Probabilitas. Yogyakarta:Center for Academic Publishing Service)

Supriyanto dan Ernawati. (2010). Pemasaran Industri Jasa Kesehatan. Yogyakarta:Andi

Undang Undang Republik Indonesia Nomor 20 tahun 2003 tentang Sistem Pendidikan Nasional.

Xu, J. Houssin R., E. Callaud dan M. Gardoni. (2010). Macro Process of Knowledge Management for Continous Innovation, Journal of Knowledge Management, Vol. 14, No. 4, h. 573-591

Yonhy, dkk. (2013). Metode Trend Non Linear untuk Forecasting Jumlah Keberangkatan Tenaga Indonesia di Kantor Imigrasi Kelas II Kabupaten Nunukan. Univ Mulawarman : Jurnal Eksponensial Vo.4 No.1 h 47-54 